\title{
Role of alkaline phosphatase intestine-isomerase in acute mesenteric ischemia diagnosis
}

\author{
Emin Lapsekili, M.D., ${ }^{1}$ Öner Menteş, M.D., ${ }^{1}$ Müjdat Balkan, M.D., ${ }^{1}$ Armağan Günal, M.D., ${ }^{2}$ \\ Halil Yaman, M.D., ${ }^{3}$ Orhan Kozak, M.D., ${ }^{1}$ Yusuf Peker, M.D. ${ }^{1}$
}

${ }^{1}$ Department of General Surgery, Gülhane Military Medical Academy, Ankara-Turkey

${ }^{2}$ Department of Pathology, Gülhane Military Medical Academy, Ankara-Turkey

${ }^{3}$ Department of Biochemistry, Gülhane Military Medical Academy, Ankara-Turkey

\begin{abstract}
BACKGROUND: The aim of the present study was to investigate the diagnostic value of alkaline phosphatase (ALP) intestineisomerase, plasma lactate dehydrogenase (LDH), and D-dimer levels in acute mesenteric ischemia.

METHODS: Thirty Wistar rats were divided into 5 groups of 6 rats each. In Group I, blood samples were obtained to determine normal parameter levels. In the sham group, Group 2, blood samples were obtained following laparotomy. In Group 3, blood samples were obtained 2 hours after ligation. In Groups 4 and 5, blood samples were obtained at 4 and 6 hours after ligation, respectively. Ischemic damage was assessed using a pathological scoring system. Blood samples were analyzed for hourly changes in parameters.
\end{abstract}

RESULTS: No statistically significant difference in D-dimer levels was found between ischemia groups ( $P=0.337)$. A statistically significant difference in LDH levels was found between the control group, Group I, and Group 4 ( $p=0.018)$. ALP intestine-isomerase enzyme levels were not statistically significant in other groups $(p=0.077)$.

CONCLUSION: Findings indicate that plasma LDH levels higher than $1900 \mathrm{IU} / \mathrm{L}$ may be a useful marker in the early diagnosis of acute mesenteric obstruction. However, ALP intestine-isomerase enzyme and D-dimer plasma levels were not found to contribute to the diagnosis.

Keywords: Acute mesenteric ischemia; ALP intestine-isomerase; D-dimer; LDH.

\section{INTRODUCTION}

Mesenteric ischemia is a clinical condition involving decreased or totally obstructed flow of blood to the intestines, manifesting as either acute or chronic. ${ }^{[I]}$

Acute mesenteric ischemia (AMI) is seen in $1-2 \%$ of all acute abdomen emergencies. However, difficulties in diagnosis may lead to increased mortality. ${ }^{[2]}$ The AMI mortality rate has remained the same for years, in spite of developments

Address for correspondence: Emin Lapsekili, M.D. Gülhane Askeri Tıp Akademisi, Genel Cerrahi Anabilim Dalı Harp Cerrahisi Bilim Dalı, Etlik, Ankara, Turkey Tel: +90 312 - 3041723 E-mail: lapsekiliemin@yahoo.com

Qucik Response Code Ulus Travma Acil Cerrahi Derg 2016;22(2): $115-120$ doi: $10.5505 /$ tjtes.2015.49475

Copyright 2016 TJTES in diagnostic methods. ${ }^{[3]}$ It has been well documented in clinical studies that AMI has a mortality rate of $50-70 \% .{ }^{[4]}$ It has been reported in a majority of reviewed studies that the most significant contributing factor to the mortality rate is late diagnosis. AMI is most commonly encountered in the geriatric population. High index of suspicion plays a strong role in quick diagnosis of $A M I$ in patients with abdominal pain and contradictory physical examination findings with clinical symptoms. Another important clue for diagnosis is that $95 \%$ of patients with embolism-induced AMI have a history of heart disease. ${ }^{[1]}$

There are radiological alternatives in AMI diagnosis. In addition to radiological instruments, biochemical markers may aid in early diagnosis, including aspartate transaminase (AST), alanine transaminase (ALT), gamma-glutamyl transpeptidase (GGT), amylase, lactate, potassium, $\mathrm{pH}$, leukocytes and Ddimer. $^{[5]}$ In addition, level of lactate dehydrogenase (LDH) enzyme, converting pyruvate to lactate, is used in diagnosis. While specificity of $\mathrm{LDH}$ in diagnosis of intestinal ischemia is known, LDH may also be increased in many other clinical conditions, such as myocardial infarction. 
In the present experimental study, the role of alkaline phosphatase (ALP) intestine-isomerase levels in diagnosis of AMI was examined.

\section{MATERIALS AND METHODS}

The present study was supported by the Research Foundation of the Gülhane Military Medical Academy and was approved by the research and animal ethics committees.

Thirty female albino Wistar rats were randomly divided into 5 groups of 6 rats each. In Group I, blood samples were obtained to determine normal levels of plasma LDH, D-dimer, and ALP intestine-isomerase after anesthesia. Blood samples were obtained from the sham group, Group 2, after laparotomy. In Group 3, blood samples were obtained 2 hours after ligation. In Groups 4 and 5, blood samples were collected at 4 and 6 hours after ligation, respectively. Ischemic damage was graded with pathological scoring system of the dissected jejunum. All blood samples were analyzed hourly for changes in serum LDH, D-dimer, and ALP intestine-isomerase. Induction of anesthesia was performed using $50 \mathrm{mg} / \mathrm{kg}$ intramuscular ketamine sodium (Ketalar ${ }^{\circledR}$; Eczacıbaşı, İstanbul, Turkey) and $25 \mathrm{mg} / \mathrm{kg}$ intramuscular $\propto$ xylazine hydrochloride (Rompun $\mathrm{Flk}^{\circledR}$; Bayer, İstanbul, Turkey). In the 12 hours leading up to surgery, rats consumed only tap water. Superior mesenteric artery ligation was performed with $4 / 0$ polypropylene (Prolene ${ }^{\circledR}$; Ethicon Inc., Somerville, NJ, USA) at the aforementioned time intervals.

\section{Pathological Examination}

Removed jejunum samples were dissected at the anti-mesenteric side of the intestine and left for fixation in 10\% formaldehyde solution for 12 hours. Following fixation, all jejunum samples were sliced horizontally. After routine pathological tissue follow-up procedures, $5 \mathrm{\gamma m}$-thick sections prepared from tissue specimens were embedded in paraffin blocks using a microtome. All specimens were stained with hematoxylin-eosin and microscopically examined with 100x magnification to determine ischemic intestinal damage grading using Park's scoring system (Table I). ${ }^{[6]}$

\section{Biochemical Examination}

Blood samples were collected in routine biochemical tubes, and serum was separated by centrifuge at $4000 \mathrm{rpm}$ for 10 minutes. Tubes were divided into 2 groups, I of which was placed in an Olympus AU2700 auto-analysis machine for spectrophotometric LDH measurements. The other was kept in $-70^{\circ} \mathrm{C}$ until all samples were processed, at which time, they were placed in a Sebia machine that utilized agarose gel electrophoresis and ALP intestine-isomerase enzyme levels of all samples were measured.

Blood samples kept in citrate tubes were centrifuged at 3000 rpm for 10 minutes to separate serum for D-dimer measure-
Table I. Park's pathological scoring system

\begin{tabular}{ll}
\hline Score & Pathology \\
\hline 0 & Normal \\
\hline & Desquamation on mucosal cells without necrosis \\
2 & Mucosal villus necrosis with crypts saved \\
3 & Mucosal villus necrosis with cryptic involvement \\
4 & Innermost muscular tissue necrosis or thinning of \\
& muscular tissue with mucosal necrosis \\
5 & Transmural necrosis \\
\hline
\end{tabular}

ments. Plasma D-dimer levels were determined with immunoturbidimetry on STA Compact ${ }^{8}$ machine with kit (Diagnostica Stago Inc., Parsippany, NJ, USA).

\section{Statistical Analysis}

Data were analyzed using SPPS software (version 15.0; SPSS Inc., Chicago, IL, USA). Kolmogorov-Smirnov test was used to analyze distribution of variables. LDH and D-dimer variables were found to be normally distributed, and Mann-Whitney $U$ test was applied. Values of ALP intestine-isomerase enzyme were skewed, and Kruskal-Wallis test was used to analyze differences in enzyme levels among ischemic and nonischemic groups. Chi-square test was used to compare pathologic scores of ischemic and nonischemic groups. Receiver operating characteristic (ROC) curve was used to compare efficiency of the 3 enzyme parameters by plotting sensitivity vs I-specificity for several possible decision levels. All $p$ values of enzyme parameters less than .05 were considered statistically significant.

\section{RESULTS}

No mortality was observed. Following pathological examination, intestinal ischemia levels were compared with the nonischemic control (Group I) and sham (Group 2) groups, using chi-square test. Statistically significant differences were found between these groups and the ischemia groups $(p=0.00 \mathrm{I})$. Distribution of Park's scores is presented in Figure I.

Grade I-2 mucosal ischemic properties were found in Group 3 (of 2nd hour ischemia; Fig. 2a, b). Grade 2-3 and 4 ischemic damage were found in ischemic Groups 4 and 5 (Fig. $2 c, d)$. No statistically significant relationship was determined among ischemic Groups 3, 4, and 5, regarding pathological damage $(p=0.345)$.

No significant difference was found in D-dimer enzyme levels among ischemic Groups 3, 4, and $5(p=0.337)$. Statistically significant difference was found in serum LDH levels of Groups I and $4(p=0.018)$. No statistically significant difference in ALP intestine-isomerase enzyme level was found among the groups $(p=0.077)$. 


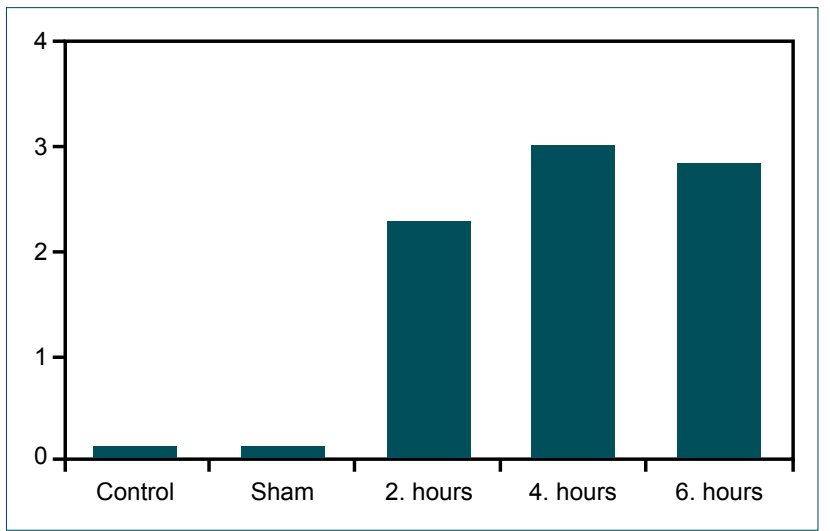

Figure 1. Distribution of Park's scores among groups.

As sham and control groups (Groups I and 2) were considered nonischemic, and Groups 3, 4, and 5 were considered ischemic, differences in inter-LDH levels were statistically significant $(p=0.038)$. However, differences in $D$-dimer and ALP intestinal enzyme levels between the ischemic and nonischemic groups were not statistically significant $(p=0.161$ and $p=0.082$, respectively). Differences in LDH levels of the nonischemic and ischemic groups were statistically significant, with ROC curves over the $1900 \mathrm{IU} / \mathrm{L}$ threshold, resulting in $94 \%$ sensitivity and $41 \%$ specificity.
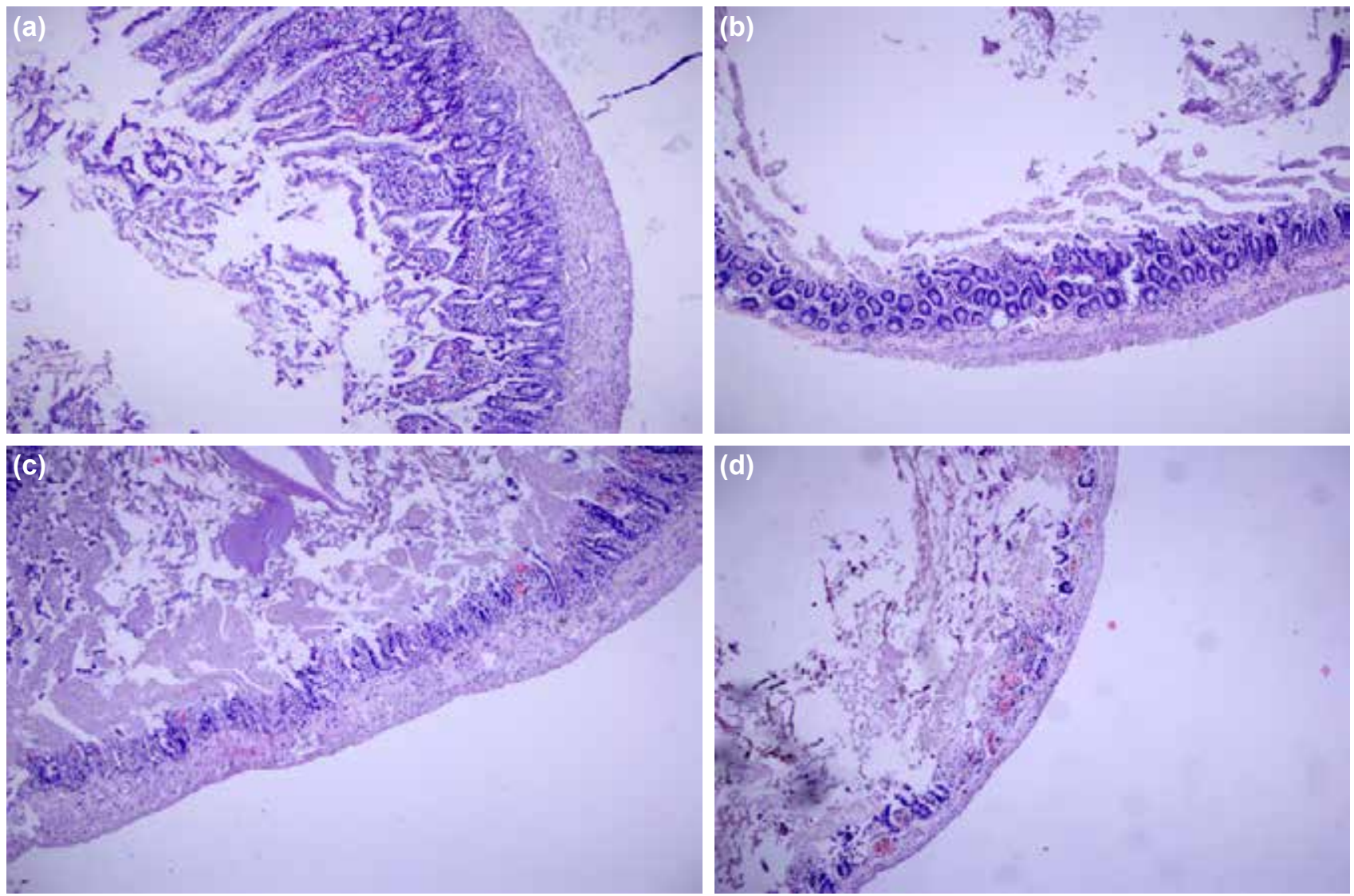

Figure 2. (a) Shedding in Parks Score 1 , damaged intestinal mucosal cells without necrosis (H-E x100). (b) Intestinal villus damage in Parks Score 2, intestinal damage with saved crypts (H-E x100). (c) Mucosal villus necrosis with cryptic involvement in Parks Score 3, intestinal damage (H-E x100). (d) Parks Score 4, intestinal damage with innermost part of muscular tissue necrosis or thinning in muscular tissue with mucosal necrosis (H-E x100). 


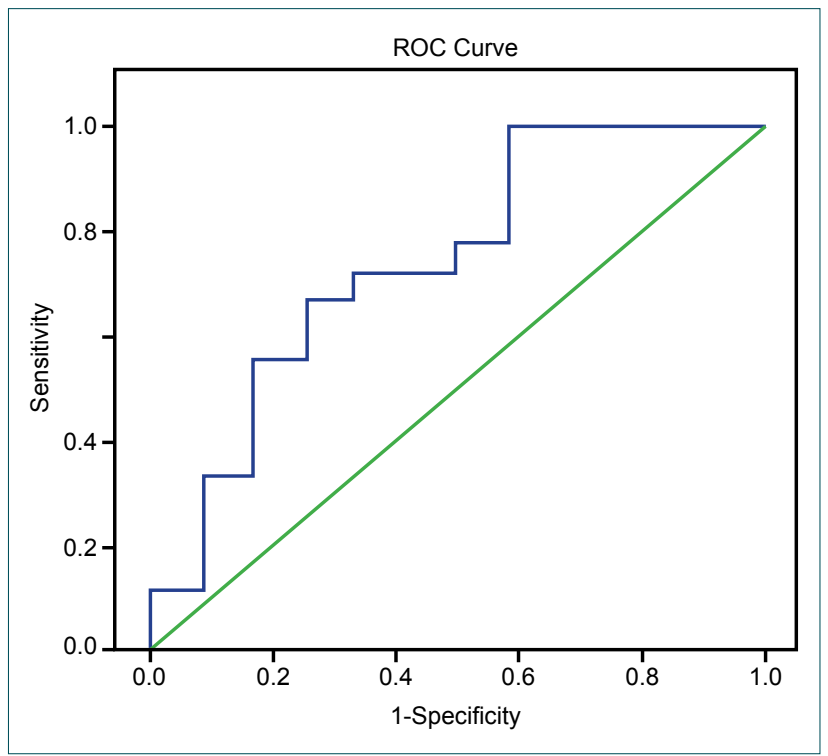

Figure 3. The ROC curve of LDH comparring of ischemic and nonischemic groups to determine AMI diagnosis.

inadequate physical exam findings and previous heart disease history is common in the geriatric population, suggesting that AMI may not always present with unique symptoms. Unfortunately, no gold standard early diagnostic tool is currently available. The present study was designed to examine the previously unstudied role of ALP intestine-isomerase in the early diagnosis of AMI.

Radiological findings are more important than laboratory markers in the diagnosis of AMI, and radiological studies now tend toward CT and spiral CT in place of DSA. Kirkpatrick et al. ${ }^{[1]}$ reported diagnostic CT sensitivity of $96 \%$ and specificity of $94 \%$, while Taourel et al. ${ }^{[12]}$ reported sensitivity of $95 \%$ and specificity of lower than $30 \%$. Meanwhile, a multi-institutional study reported a specificity near $100 \%$ with multislice CT, overcoming the $88 \%$ specificity rate achieved by the prior gold standard diagnostic tool, DSA. ${ }^{[13,14]}$

The most common biochemical pathologies in AMI patients are hemoconcentration, leukocytosis, and high anion-gap metabolic acidosis. In previous initial biochemical assessments of serum amylase, aspartate aminotransferase, LDH, and creatine phosphokinase, levels had not reached sensitivity and specificity rates sufficient to aid in diagnosis of AMI. Hyperphosphatemia and hyperkalemia are late findings, usually accompanying intestinal necrosis. ${ }^{[15]}$ Hypovolemia and its effects on kidneys could lead to high serum amylase levels responsible for intestinal inflammation. Approximately $50 \%$ of patients had metabolic acidosis as late intestinal ischemic finding, while $25 \%$ had hyperamylasemia. ${ }^{[6]}$

In an experimental study, Zhang et al. demonstrated that biochemical markers of ALT, AST, ALP, GGT, and LDH rose after 3 hours of ischemic period. ${ }^{[17]}$ Karaağaç et al. showed in an experimental study that IL-IB, IL-6, and TNF- $\alpha$ levels rose in the $2^{\text {nd }}$ and $4^{\text {th }}$ hour after ischemic period. ${ }^{[18]}$ In an experimental study of mesenteric artery ischemia conducted by Gunduz et al., ischemia-modified albumin was found to be significantly increased at the $2^{\text {nd }}$ and $4^{\text {th }}$ hour after ischemic period, though future research is warranted. ${ }^{[19]}$

In an experimental study conducted by Uncu et al., ALT, AST, ALP, LDH, creatine kinase, and phosphorus levels rose in the first hour after the ischemic period, but none of those parameters were sufficiently specific for diagnosis of AMI.[20] In an experimental study conducted by Gönüllü et al., peritoneal lavage fluid samples of arterial occlusion were analyzed for $\mathrm{pH}$ and potassium levels, then compared with blood $\mathrm{pH}$ levels. It was demonstrated that within the first 30 and 60 minutes, $\mathrm{pH}$ levels of the lavage fluid dropped, and potassium levels rose, a finding that could be of early diagnostic importance. [21] In a similar study conducted by Ljungdahl et al., using an experimental pig model, it was reported that superficial intestinal mucosa $\mathrm{pH}$ levels dropped from 7.28 to 6.76 , with high superior mesenteric vein lactate levels. ${ }^{[22]}$

Sonnino et al. found strong statistical correlation between intestinal ischemia and levels of fatty acid-binding proteins in peritoneal fluid normally found only in intestinal mucosa villus tips, not in the circulatory system. ${ }^{[23]}$ Diagnostic use of inert Xenon $\left(\mathrm{Xe}^{54}\right)$ gas is promising in early diagnosis of $\mathrm{AMI}-$ when dissolved in salt and injected into the peritoneal cavity, it is absorbed with passive diffusion into the intestine. While tissues with normal perfusion can clean this gas easily, ischemic tissues cannot. ${ }^{[24]}$ Lange et al. reported rise in level of lactate as the best serum marker in acute abdomen diagnosis, with $100 \%$ sensitivity and $42 \%$ specificity. ${ }^{[25]}$

In the present study, serum LDH levels were found to be statistically significant when control and fourth-hour ischemia groups were compared, while intergroup comparisons showed no statistically significant difference in enzyme levels. When LDH serum levels were compared among the nonisch-

Table 2. Mean values of ischemic and nonischemic groups

\begin{tabular}{lcccc}
\hline Pathology & $\mathbf{n}$ & LDH (IU/L) & D-dimer (ng/mI) & IALP (\%) \\
\hline Non-ischemic & 12 & 2758.67 & 319.58 & 12.08 \\
Ischemic & 18 & 4947.28 & 180.06 & 17.78 \\
\hline P value: ${ }^{\mathrm{c}}(0.036),{ }^{\mathrm{b}}(0.161),{ }^{\mathrm{c}}(0.082)$. LDH: Lactate dehydrogenase. IALP: Intestinal alkaline phosphatase.
\end{tabular}


emic control (Group I) and sham (Group 2) groups, and the ischemic groups (Groups 3, 4, and 5), LDH serum levels in the ischemic groups were found to be statistically significant, with $94 \%$ sensitivity and $41 \%$ specificity $(p=0.038)$ (Figure 3$)$.

D-dimer is a marker that rises in most thrombolytic cases as a byproduct of fibrin degradation. ${ }^{[26]}$ Most surgical trauma and tissue degradation results in coagulation and activation of the fibrinolytic system. Therefore, D-dimer sensitivity and specificity in surgical practice is quite low. ${ }^{[2]}$ Studies that report D-dimer measurement results make important contributions to diagnostic methods. ${ }^{[5]}$ In an experimental study of mesenteric artery ligation in rats, Altinyollar et al. found increased D-dimer levels with statistical significance when the data of the sham group was compared to that of the seventh-hour ischemia group. ${ }^{[28]}$ Acosta-Mérida et al. reported that 6 patients treated for AMI had significantly higher D-dimer results, compared to the 8 who had not undergone treatment. ${ }^{[29,30]} \mathrm{A}$ similar study conducted by Kulacoglu et al. reported a significant rise in $\mathrm{D}$-dimer levels of the sixth-hour ischemia group. ${ }^{\left[{ }^{3]}\right]}$

In the present study, similar levels of D-dimer were found in the ischemic rat model and the control and sham groups (avg. $=235 \mathrm{ng} / \mathrm{mL}$ ). The authors hypothesize that in early-term ischemia, rise in degradation products may not cause increase in D-dimer level (discouraging its use in early diagnosis, compared to its possible use in late diagnosis). The authors suggest that normal levels of D-dimer at an early stage cannot rule out diagnosis of ischemia. High index of suspicion with immediate attempts at early diagnosis and emergency angiography for thrombolytic treatment should not be delayed in cases of AMI. ${ }^{[32]}$

ALP intestine-isomerase enzyme is present in high concentrations in intestinal epithelial cells, and is responsible for calcium absorption and transport of fatty acids. ${ }^{[33]}$ In the present study, the physiological role of a possible increase or decrease of ALP intestine-isomerase enzymes in intestinal ischemia was examined, and the potential of enzyme measurement to be used in AMI diagnosis was assessed. No statistically significant results were found with regard to difference in enzyme levels, either intergroup or between the ischemic and nonischemic groups. However, in qualitative analysis, the rise in enzyme levels concurrent with the period of ischemia was noteworthy. Future studies with larger groups are warranted to evaluate ALP intestinal isomerase levels in diagnosis of AMI.

In the present experimental study, no significant difference in ALP intestinal isomerase enzyme levels were found between the ischemic and nonischemic groups, while differences in LDH levels were statistically significant $(p=0.036$; Table 2$)$. A gradual increase in LDH levels was determined in the ischemic groups, beginning at the first hour and continuing throughout the ischemic period.

In conclusion, the present findings suggest that LDH plasma levels above $1900 \mathrm{IU} / \mathrm{L}$ may be a useful marker in the early diagnosis of acute mesenteric obstruction, while ALP intestinal isomerase enzyme and D-dimer plasma levels did not contribute to the diagnosis of acute mesenteric ischemia.

\section{Conflict of interest: None declared.}

\section{REFERENCES}

1. Adams JT. Abdominal wall, omentum, mesentery and retroperitoneum. In: Schwartz SI, Shires TG, Spencer FC, editors. Principles of surgery. 6th ed. New York: Mc Graw Hill Co; 1994. p. 1495-504.

2. Yasuhara H. Acute mesenteric ischemia: the challenge of gastroenterology. Surg Today 2005;35:185-95. CrossRef

3. Turnage RH, Badgwell B. Abdominal wall, umblicus, peritoneum, mesenteries, omentum and retroperitoneum. In: Townsend CM Jr, Beauchamp D, Evers BM, Mattox KL, editors. Sabiston textbook of surgery. 18th ed., Philadelphia: Saunders; 2008. p. 1129-54.

4. Luther B, Moussazadeh K, Müller BT, Franke C, Harms JM, Ernst S, et al. The acute mesenteric ischemia - not understood or incurable?. [Article in German] Zentralbl Chir 2002;127:674-84. [Abstract] CrossRef

5. Kurt Y, Akin ML, Demirbas S, Uluutku AH, Gulderen M, Avsar K, et al. $\mathrm{D}$-dimer in the early diagnosis of acute mesenteric ischemia secondary to arterial occlusion in rats. Eur Surg Res 2005;37:216-9. CrossRef

6. Park PO, Haglund U, Bulkley GB, Fält K. The sequence of development of intestinal tissue injury after strangulation ischemia and reperfusion. Surgery 1990;107:574-80.

7. Klein HM, Lensing R, Klosterhalfen B, Töns C, Günther RW. Diagnostic imaging of mesenteric infarction. Radiology 1995;197:79-82. CrossRef

8. Wiesner W, Hauser A, Steinbrich W. Accuracy of multidetector row computed tomography for the diagnosis of acute bowel ischemia in a nonselected study population. Eur Radiol 2004;14:2347-56. CrossRef

9. Boley SJ, Brandt LJ, Veith FJ. Ischemic disorders of the intestines. Curr Probl Surg 1978;15:1-85. CrossRef

10. Luther B, Moussazadeh K, Müller BT, Franke C, Harms JM, Ernst S, et al. The acute mesenteric ischemia - not understood or incurable?. [Article in German] Zentralbl Chir 2002;127:674-84. [Abstract] CrossRef

11. Kirkpatrick ID, Kroeker MA, Greenberg HM. Biphasic CT with mesenteric CT angiography in the evaluation of acute mesenteric ischemia: initial experience. Radiology 2003;229:91-8. CrossRef

12. Taourel PG, Deneuville M, Pradel JA, Régent D, Bruel JM. Acute mesenteric ischemia: diagnosis with contrast-enhanced CT. Radiology 1996;199:632-6. CrossRef

13. Yikilmaz A, Karahan OI, Senol S, Tuna IS, Akyildiz HY. Value of multislice computed tomography in the diagnosis of acute mesenteric ischemia. Eur J Radiol 2011;80:297-302. CrossRef

14. Wolf EL, Sprayregen S, Bakal CW. Radiology in intestinal ischemia. Plain film, contrast, and other imaging studies. Surg Clin North Am 1992;72:107-24.

15. May LD, Berenson MM. Value of serum inorganic phosphate in the diagnosis of ischemic bowel disease. Am J Surg 1983;146:266-8. CrossRef

16. Tsai CJ, Kuo YC, Chen PC, Wu CS. The spectrum of acute intestinal vascular failure: a collective review of 43 cases in Taiwan. Br J Clin Pract 1990;44:603-8.

17. Zhang FX, Zhang CM, Hu L. The effect of examination of enzymes in serum to diagnosis of acute mesenteric ischemia in rabbit. [Article in Chinese] Zhonghua Wai Ke Za Zhi 2005;43:430-2. [Abstract]

18. Karaağaç H, Zeybek N, Peker Y, Yağcı G, Şengül A, Günhan Ö, et al. Diagnostic value of plasma cytokine levels in acute mesenteric ischemia: an experimental study. Gulhane Med J 2007;49: 216-21.

19. Gunduz A, Turkmen S, Turedi S, Mentese A, Yulug E, Ulusoy H, et al. Time-dependent variations in ischemia-modified albumin levels in mes- 
enteric ischemia. Acad Emerg Med 2009;16:539-43. CrossRef

20. Uncu H, Uncu G, İlçölY, Aker Y. Diagnosis of intestinal ischemia by measurement of serum phosphate and enzyme changes and the effectiveness of vitamin E treatment. The Turkish J of Gastroenterol 1999;10:272-5.

21. Gönüllü D, Yankol Y, Ișiman F, Akyildiz Iğdem A, Yücel O, Köksoy FN. $\mathrm{pH}$ value and potassium level of diagnostic peritoneal lavage fluid in the early diagnosis of acute mesenteric ischemia secondary to arterial occlusion in rats. [Article in Turkish] Ulus Travma Acil Cerrahi Derg 2007;13:261-7.

22. Ljungdahl M, Rasmussen I, Raab Y, Hillered L, Haglund U. Small intestinal mucosal $\mathrm{pH}$ and lactate production during experimental ischemiareperfusion and fecal peritonitis in pigs. Shock 1997;7:131-8. CrossRef

23. Sonnino R, Ereso G, Arcuni J, Franson R. Human intestinal fatty acid binding protein in peritoneal fluid is a marker of intestinal ischemia. Transplant Proc 2000;32:1280. CrossRef

24. Schrock TR. Acute vascular lesions of the small intestine $\&$ mesentery. In: Way Lawrence W, editor. Surgical diagnosis $\&$ treatment. 9th ed. California: Appleton\&Lange; 1991. p. 626.

25. Lange H, Jäckel R. Usefulness of plasma lactate concentration in the diagnosis of acute abdominal disease. Eur J Surg 1994;160:381-4.

26. Meyer T, Klein P, Schweiger H, Lang W. How can the prognosis of acute mesenteric artery ischemia be improved? Results of a retrospective analy- sis. [Article in German] Zentralbl Chir 1998;123:230-4. [Abstract]

27. Owings JT, Gosselin RC, Anderson JT, Battistella FD, Bagley M, Larkin EC. Practical utility of the D-dimer assay for excluding thromboembolism in severely injured trauma patients. J Trauma 2001;51:425-30.

28. Altinyollar $\mathrm{H}$, Boyabatli M, Berberoğlu U. D-dimer as a marker for early diagnosis of acute mesenteric ischemia. Thromb Res 2006;117:463-7.

29. Acosta-Mérida MA, Marchena-Gómez J, Cruz-Benavides F, HernándezNavarro J, Roque-Castellano C, Rodríguez-Méndez A, et al. Predictive factors of massive intestinal necrosis in acute mesenteric ischemia. [Article in Spanish] Cir Esp 2007;81:144-9. [Abstract] CrossRef

30. Acosta S, Björck M. Acute thrombo-embolic occlusion of the superior mesenteric artery: a prospective study in a well defined population. Eur J Vasc Endovasc Surg 2003;26:179-83. CrossRef

31. Kulacoglu H1, Kocaerkek Z, Moran M, Kulah B, Atay C, Kulacoglu S, et al. Diagnostic value of blood D-dimer level in acute mesenteric ischaemia in the rat: an experimental study. Asian J Surg 2005;28:131-5. CrossRef

32. Doğtaş A, Solak O, Topçu Ö, Duman M. Selective Intra-arterial Thrombolytic Treatment of the Acute Thromboembolism of the Superior Mesenteric Artery. C.U. Journal of Medicine 2005;27:79-82.

33. Calbreath FD. Clinical chemistry a fundamental textbook. Philadelphia: W.B. Saunders Company. 1992.p. 186-90.

\section{DENEYSEL ÇALIŞMA - ÖZET}

\section{Alkalen fosfataz bağırsak izomeraz enziminin akut mezenterik iskemi tanısındaki rolü \\ Dr. Emin Lapsekili,, ${ }^{1}$ Dr. Öner Menteş, ${ }^{1}$ Dr. Müjdat Balkan, ${ }^{1}$ Dr. Armağan Günal, ${ }^{2}$ Dr. Halil Yaman, ${ }^{3}$ Dr. Orhan Kozak, ${ }^{1}$ Dr. Yusuf Peker ${ }^{1}$}

${ }^{1}$ Gülhane Askeri Tıp Akademisi, Genel Cerrahi Anabilim Dalı, Ankara

${ }^{2}$ Gülhane Askeri Tıp Akademisi, Patoloji Anabilim Dalı, Ankara

${ }^{3}$ Gülhane Askeri Tıp Akademisi, Biyokimya Anabilim Dalı, Ankara

AMAÇ: Çalışmamızdaki amacımız, akut mezenterik iskeminin erken tanısında alkalen fosfataz (ALP) bağırsak izomeraz enzim düzeyleri ile birlikte $\mathrm{LDH}$ ve D-dimer düzeylerinin değerini belirlemektir.

GEREÇ VE YÖNTEM: Otuz adet wistar cinsi sıçan her grupta altı sıçan olmak üzere beş gruba ayrıldı. Birinci grup kontrol grubu: Normal sıçandaki ALP-bağırsak izomeraz, LDH ve D-dimer düzeylerini belirlemek için girişim yapılmadan sadece kan alınan grup. İkinci grup sham: Sadece laparotomi yapılarak kan örneği alınan grup. Üçüncü grup: Superior mezenterik arter ligasyonu sonrasındaki ikinci saatte kan örneği alınan grup. Dördüncü ve beşinci grup; sırasıyla ligasyon sonrası dördüncü ve altıncı saatlerde kan örneği alınan grup. Bağırsaktaki iskemik hasar patolojik olarak sınıflandırıldı. Tüm kan örnekleri parametrelerdeki saatlik değişimlerini saptamak amacıyla biyokimyasal olarak değerlendirildi.

BULGULAR: İskemi grupları arasında $D$-dimer sonuçları belirgin olarak anlamlı bulunmadı $(p=0.337)$. LDH seviyeleri birinci ve dördüncü deney grubu arasında anlamlı bulundu $(p=0.018)$. ALP-bağırsak izomeraz enzim düzeyleri tüm diğer gruplar arasında anlamlı değildi $(p=0.077)$.

TARTIŞMA: Bulgularımız ALP-bağırsak izomeraz enzimi ve D-dimer düzeylerinin, akut mezenterik iskeminin erken döneminde, tanısal olarak değerli olmamasına rağmen $1900 \mathrm{IU} / \mathrm{L}$ üzerindeki LDH düzeylerinin kullanışlı bir tanısal belirteç olabileceğini göstermektedir.

Anahtar sözcükler: Akut mezenterik iskemi; ALP-bağırsak izomeraz; D-dimer; LDH.

Ulus Travma Acil Cerrahi Derg 2016;22(2):II5-120 doi: 10.5505/tjtes.2015.49475 